\title{
New record of a very specialized interaction: Myrcidris epicharis Ward 1990 (Pseudomyrmecinae) and its myrmecophyte host Myrcia madida McVaugh (Myrtaceae) in Brazilian Meridional Amazon
}

Ricardo Eduardo VICENTE'; Wesley DÁTTILO²; Thiago Junqueira IZZO ${ }^{1,3}$

ABSTRACT

In this study we present a new record of a plant-animal interaction: the mutualistic relationship between the specialist plantant Myrcidris epicharis Ward, 1990 (Pseudomyrmecinae) and its myrmecophyte host Myrcia madida McVaugh (Myrtaceae). We observed more than 50 individuals of $M$. madida occupied by $M$. epicharis in islands and margins of the Juruena River, in Cotriguaçu, Mato Grosso, Brazil (Meridional Amazon). We discuss a possible distribution of this symbiotic interaction throughout all the riparian forest of the Amazon River basin and its consequence to coevolution of the system.

KEYWORDS: Ant-plant; Mutualism; Geographic distribution; Amazon River basin.

\section{Novo registro de uma interação altamente especializada: Myrcidris epicharis Ward 1990 (Pseudomyrmecinae) e sua mirmecófita hospedeira Myrcia madida McVaugh (Myrtaceae) na Amazônia Meridional brasileira RESUMO}

Neste estudo nós apresentamos um novo registro de uma interação planta-animal: a relação mutualística entre a formiga especialista Myrcidris epicharis Ward, 1990 (Pseudomyrmecinae) e sua mirmecófita hospedeira Myrcia madida McVaugh (Myrtaceae). Observamos mais de 50 plantas de $M$. madida ocupadas por $M$. epicharis em ilhas e margens do rio Juruena, no município de Cotriguaçu, Estado de Mato Grosso, Brasil (Amazônia Meridional). Discutimos a possível distribuição dessa interação simbiótica através de florestas ripária da bacia do Rio Amazonas e suas conseqüências para a coevolução do sistema. PALAVRAS-CHAVE: Formiga-planta; Mutualismo, Distribuição geográfica; Bacia do rio Amazonas.

\footnotetext{
1 Núcleo de Estudos da Biodiversidade da Amazônia Mato-grossense, Universidade Federal de Mato Grosso, Sinop, Mato Grosso, Brazil. and Programa de Pós-Graduação em Ecologia e Conservação da Biodiversidade, Universidade Federal de Mato Grosso, Cuiabá, Mato Grosso, Brazil. E-mail: ricardomyrmex@gmail.com

2 Instituto de Neuroetología, Universidad Veracruzana, Xalapa, VZ, Mexico. E-mail: wdattilo@hotmail.com

${ }^{3}$ Núcleo de Estudos da Biodiversidade da Amazônia Mato-grossense, Universidade Federal de Mato Grosso, Sinop, Mato Grosso, Brazil. and Departamento de Ecologia e Botânica, Universidade Federal de Mato Grosso, Cuiabá, Mato Grosso, Brazil. E-mail: izzothiago@gmail.com
} 
In the tropics there are more than 150 plant species known as myrmecophytes. Various have trunks, modified spines, leaf bags and other structures, also called domatia (Benson 1985; Mckey and Davidson 1993), where highly specialized ant species establish their colonies (Benson 1985; Rico-Gray and Oliveira 2007; Dáttilo et al. 2009a). In exchange for shelter and food, in some cases (Beattie 1985; Vasconcelos 1991; Leroy et al. 2008), the ants defend their host plants against potential herbivores (Fonseca and Ganade 1996; Stapley 1998; Heil 2003). Myrmecophytes and ants have specializations that make the interaction essential to the life cycle of both (Bronstein 2006), so that they have only one or few possible associations (Fonseca and Ganade 1996; Guimarães et al. 2007). To investigate whether the specificity of a interaction varies along the geographical range of both mutualistic species may provide insights on ecology and evolution of myrmecophytes (Murase et al. 2003; Bronstein 2009; Moraes and Vasconcelos 2009).

The subfamily Pseudomyrmecinae comprises more than 300 described species, of which more than 40 are exclusive inhabitants of myrmecophytes (Ward and Downie 2005). Among the three genera that comprise this subfamily, Myrcidris has only two species: Myrcidris epicharis Ward, 1990 and an undescribed species collected only once in the Kurupukari region, Northern Amazon, Guyana (Ward, pers. comm.).

Since the original description, $M$. epicharis has been reported only from rainforest areas near Manaus, Amazonas, in Central Amazon, Brazil (Ward 1990; Bruna et al. 2005; Ferreira and Vasconcelos 2010). Little is known about this species, but $M$. epicharis has an extremely intimate relationship with the myrmecophyte Myrcia madida McVaugh (Myrtaceae) (Ferreira and Vasconcelos 2010). A single ant specimen was collected near Amacayacu, Amazonas department in Western Amazon, Colombia (Guerrero 2009). This specimen was captured by a Malaise trap. Thus, we can not say whether $M$. epicharis is or not associated with M. madida in this region, since this record can be considered accidental (Guerrero 2009).

Myrcia madida is the only species of a very species-rich genus (ca. 300 spp.) which has domatia and, consequently, association with ants (Benson 1985). Based on a few records, it is estimated that the occurrence of this myrmecophyte covers the entire Amazon basin along the margins of the Rio Napo (Peru) to Solimões River basin (Brazil) (Mcvaugh 1956; Mcvaugh 1958; Ferreira and Vasconcelos 2010; Herbweb 2011). In this work we record a new locality with this specific interaction, contributing to the expansion of its known distribution. In addition, we discuss biogeographical aspects of both species.
This new record was made about $815 \mathrm{~km}$ in linear distance and approximately $2.140 \mathrm{~km}$ by tributaries of the Amazon River from the nearest occurrence known until now, the region of Manaus, Central Amazon, Brazil. Specimens of ants and myrmecophytes were collected in October 2010 from islands and along the margins of the Juruena River in Cotriguaçu, Mato Grosso, Brazil (0952'50”S; 58¹2'52”W, elev. 196 m) (Figure 1). According to Köppen classification, the climate is tropical humid $(\mathrm{Am})$, with average annual temperature of $24^{\circ} \mathrm{C}$, humidity of $85 \%$ and average annual rainfall of 2.300 $\mathrm{mm}$ (Camargo et al. 2010). All plant samples were collected in sites with low light levels, and sent for confirmation and deposit in the Museu Paraense Emílio Goeldi (MPEG), Pará, Brazil. Ant workers were compared with paratypes and deposited at the Museu de Zoologia da Universidade de São Paulo (MZSP), São Paulo, Brazil. Additionally, ant specimens were deposited at the Bohart Museum of Entomology of University of California (UCDC), Davis, USA, and at the Setor de Entomologia of Coleção Zoológica of Universidade Federal de Mato Grosso (CEMT), Cuiabá, Brazil (Figure 2).

We observed more than 50 young and adult individuals of $M$. madida occupied by M. epicharis. We did not observe ant alates and coccoid symbionts living in the domatias. Curiously, even after intensive searching along approximately $20 \mathrm{~km}$ of trails, neither $M$. madida nor the ant M. epicharis were recorded in continuous forest near the Juruena River. Several other myrmecophyte species, as Cordia nodosa Lamark (Boraginaceae) and an unidentified Tachigalli sp. (Leguminosae - Caesalpinioideae) were found in continuous forest, hosting different ant species (Petini-Benelli and Izzo 2011) but never M. epicharis. Indeed, Bruna et al. (2005) reported that $M$. madida is extremely rare in areas of continuous forest in Central Amazon and several authors have found M. madida in areas near to rivers (Mcvaugh 1956;

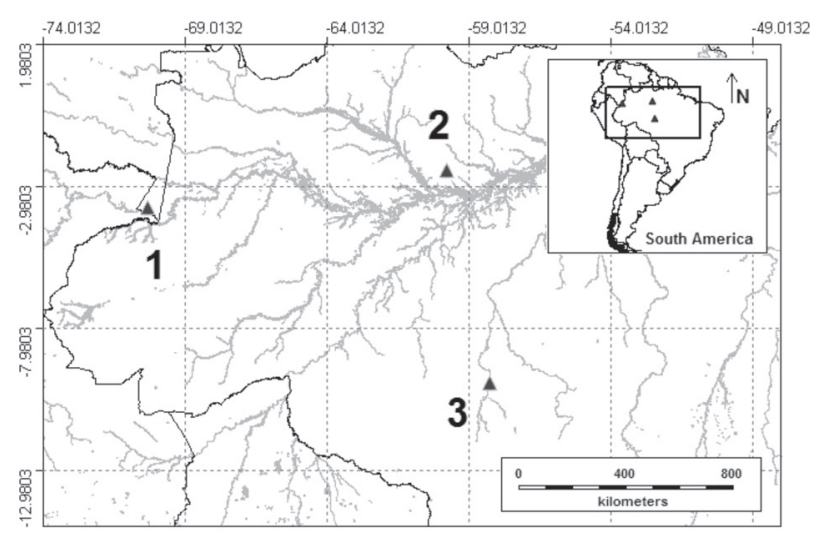

Figure 1 - Records for Myrcidris epicharis (Formicidae: Pseudomyrmecinae): 1) Guerrero 2009; 2) Ward 1990; Bruna et al. 2005; Ferreira and Vasconcelos 2010; and 3) new record. 

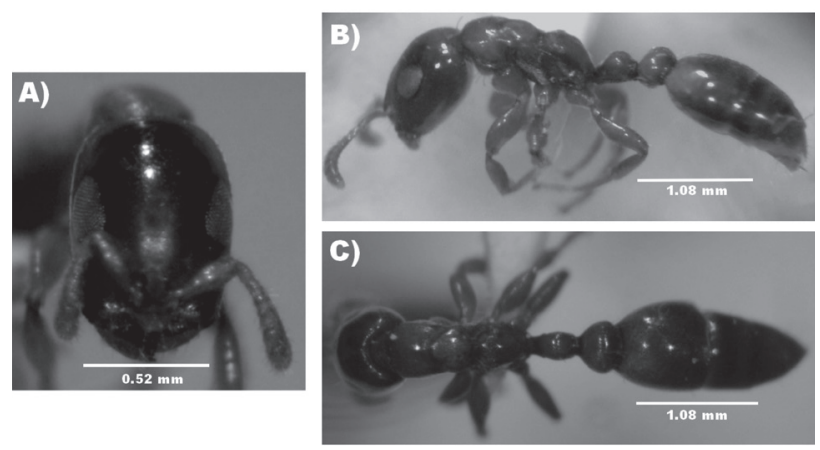

Figure 2 - Worker of Myrcidris epicharis (Formicidae: Pseudomyrmecinae) deposited in the Setor de Entomologia of Coleção Zoológica of Universidade Federal de Mato Grosso (CEMT), Cuiabá, Brazil. A) Head view. B) Lateral view. C) Dorsal view. Photo: Wesley Dáttilo.

Mcvaugh 1958; Herbweb 2011). Thus, it is possible that $M$. madida and consequently $M$. epicharis are more commonly found in areas near rivers than in continuous closed forest.

The symbiotic relationship between ants and myrmecophytes is suggested be specialized and compartmentalized (Guimarães et al. 2007). In this type of relationship both parts have different adaptations to select their association (mutualism filters) (Davidson et al. 1989; Ferdele 1997; Dáttilo et al. 2009b). In addition, observations of a variety of antmyrmecophyte systems show that the number of unoccupied myrmecophytes is extremely low (Bruna et al. 2005), including in our study area (obs. pers.). Thus, it is possible that the interaction between M. epicharis and M. madida is distributed throughout the region where $M$. madida is found. Additionally, as the dispersal strategy of this myrmecophyte is still unknown, we believe that $M$. madida may be dispersed mostly by animals living in areas near rivers throughout the Amazon basin.

\section{ACKNOWLEDGMENTS}

We would like to thank Phil S. Ward and Rodrigo Feitosa for theirs comments on earlier versions of this manuscript and Office National des Forêts Brazil by logistical support. We also thank CAPES by master fellowship to WD and CNPq by DTI fellowship to REV ( ${ }^{\circ}$ 381261/2011-5). This is publication 17 in the NEBAM technical series.

\section{REFERENCES}

Beattie, A.J. 1985. The evolutionary ecology of ant-plant mutualisms. Cambridge University Press, Cambridge, MA, USA. 182 pp.

Benson, W.W. 1985. Amazon ant-plants, p. 239-266. In: Prance, G.T.; Lovejoy, T.E. (Eds.): Amazonia. Pergamon Press, Oxford.

Bronstein, J.L.; Alarcón, R.; Geber, M. 2006. The evolution of plantinsect mutualisms. New Phytologist, 172: 412-428.

Bronstein, J.L 2009. J.L. Mutualism, p. 233-238. In: Levin, S.A.; Carpenter, S.R.; Godfray, C.J.; Kinzig, A.P.; Loreau, M.; Losos,
J.B.; Walker, B.; Wilcove, D.S. (Eds.). Princeton Guide to Ecology. Princeton University Press, New Jersey.

Bruna, E.M.; Vasconcelos, H.L.; Heredia, S. 2005. The effect of habitat fragmentation on communities of mutualists: a test with Amazonian ants and their host plants. Biological Conservation, 124: 209-216

Camargo, F.F.; Costa, R.B.; Resende, M.D.V.; Roa, R.A.R.; Rodrigues, N.B.; Santos, L.V.; Freitas, A.C.A. 2010. Variabilidade genética para caracteres morfométricos de matrizes de castanha-do-brasil da Amazônia Mato-grossense. Acta Amazonica, 40: 705-710.

Dáttilo, W., Marques, E.C., Falcão, J.C.F. \& Moreira, D.D.O. 2009a. Interações mutualísticas entre formigas e plantas. EntomoBrasilis, 2: 32-36.

Dáttilo, W.F.C.; Izzo, T.J.; Inouye, B.D.; Vasconcelos, H.L.; Bruna, E.M. 2009b. Recognition of host plant volatiles by Pheidole minutula Mayr (Myrmicinae), an amazonian ant-plant specialist. Biotropica, 41: 642-646.

Davidson, D.W.; Snelling R.R.; Longino, J.T. 1989. Competition among ants for myrmecophytes and the significance of plant trichomes. Biotropica, 21: 64-73.

Ferdele, W.; Maschwitz, U.; Fiala, Riederer, B.; Hölldobler, B. 1997. Slippery ant-plants and skilful climbers: selection and protection of specific ant partners by epicuticular wax blooms in Macaranga (Euphorbiaceae). Oecologia, 112: 217-224.

Ferreira, L.V.; Vasconcelos, H.L. 2010. On a poorly known Amazonian ant-plant association: Myrcia madida McVaugh (Myrtaceae) and Myrcidris epicharis Ward (Hymenoptera: Formicidae: Pseudomyrmecinae). Boletim do Museu Paraense Emilio Goeldi Ciências Naturais, 5: 363-367.

Fonseca, C.R.F.; Ganade, G. 1996: Asymmetries, compartments, and null interactions in Amazonian ant-plant community. Journal of Animal Ecology, 65: 339-347.

Guerrero, R.J. 2009. First record of the ant genus Myrcidris (Formicidae: Pseudomyrmecinae) from Colombia. Revista Colombiana de Entomología, 35: 103-104.

Guimarães, P.R.; Rico-Gray, V.; Oliveira, P.S.; Izzo, T.J.; Reis, S.F.; Thompson, J.N. 2007. Interaction intimacy affects structure and coevolutionary dynamics in mutualistic networks. Current Biology, 17: 1797-1803.

Heil, M.; McKey, D. 2003. Protective ant-plant interactions as model systems in ecological and evolutionary research. Annual Review of Ecology, Evolution, and Systematics, 34: 425-453.

HerbWeb, 2011. Myrcia madida - Royal Botanical Garden (http:// apps.kew.org/herbcat/getHomePageResults.do?homePageSea rch Text $=$ Myrcia + madida $\& x=0 \& y=0 \&$ homePageSearchOptio $\mathrm{n}=$ scientific_name\&nameOfSearchPage=home_page). Acesso em 25/05/2011.

Leroy, C.; Jauneau, A.; Quilichini, A.; Dejean, A.; Orivel, J. 2008. Comparison between the anatomical and morphological structure of leaf blades and foliar domatia in the ant-plant Hirtella physophora (Chrysobalanaceae). Annals of Botany, 101: 501-507.

McKey, D.; Davidson, D.W. 1993. Ant-plant symbioses in Africa and the Neotropics: history, biogeography and diversity, p. 568-606. In: Goldblatt, P. (Ed.). Biological relationships between Africa and South America. Yale University Press, New Haven. 
McVaugh, R. 1956. Tropical American Myrtaceae: Notes on generic concepts and descriptions of previously unrecognized species. Fieldiana Botany, 29: 143-228.

McVaugh, R. 1958. Myrtaceae, p.569-818. In: Macbride, J.F. (Ed.). Flora of Peru. Publications of the Field Museum of Natural History, Lima.

Moras, S.C.; Vasconcelos, H.L. 2009: Long-term persistence of a Neotropical ant-plant population in the absence of obligate plant-ants. Ecology, 90: 2375-2383.

Murase, K.; Itioka, T.; Nomura, M.; Yamane, S. 2003. Intraspecific variation in the status of ant symbiosis on a myrmecophyte Macaranga bancana, between primary and secondary forests in Borneo. Population Ecology, 45: 221-226.

Petini-Benelli, A.; Izzo, T.J. 2011. Relação entre diferentes espécies de formigas e a mirmecófita Cordia nodosa Lamarck (Boraginaceae) em áreas de mata ripária na Amazônia matogrossense. Acta Amazonica, 41(3): 355-360.
Rico-Gray, V.; P.S. Oliveira, 2007. The ecology and evolution of antplant interactions. University of Chicago Press, Chicago, USA. $331 \mathrm{pp}$.

Stapley, L. 1998. The interaction of thorns and symbiotic ants as an effective defence mechanism of swollen-thorn acacias. Oecologia, 115: 401-405.

Vasconcelos, H.L. 1991. Mutualism between Maieta guianensis Aubl., a myrmecophytic melastome, and one of its ant inhabitants: ant protection against insect herbivores. Oecologia, 87: 295-298.

Ward, P.S. 1990. The ant subfamily Pseudomyrmecinae (Hymenoptera: Formicidae): generic revision and relationship to other formicids. Systematic Entomology, 15: 449-489.

Ward, P.S.; Downie, D.A. 2005. The ant subfamily Pseudomyrmecinae (Hymenoptera: Formicidae): phylogeny and evolution of bigeyed arboreal ants. Systematic Entomology, 30: 310-335.

Recebido em: 10/08/2011

Aceito em: 28/11/2011 